\title{
Article/Artigo
}

\section{Slow clinical improvement after treatment initiation in Leishmania/HIV coinfected patients}

\author{
Melhora clínica após o início do tratamento em pacientes portadores de co-infecção \\ Leishmania/HIV
}

Guenael Freire de Souza ${ }^{1}$, Fernando Biscione ${ }^{1}$, Dirceu Bartolomeu Greco ${ }^{1}$ and Ana Rabello ${ }^{2}$

\begin{abstract}
Introduction: In Brazil there is a large area of overlap of visceral leishmaniasis (VL) and HIV infection, which favored a increased incidence of coinfection Leishmania/HIV. Methods: This study evaluated 65 consecutive patients with VL and their clinical response to treatment in two health care settings in Belo Horizonte, Brazil. Results: At baseline, the clinical picture was similar between both groups, although diarrhea and peripheral lymphadenomegaly were more frequent in HIV-infected subjects. HIV-positive patients had lower median blood lymphocyte counts $\left(686 / \mathrm{mm}^{3}\right.$ versus $\left.948 / \mathrm{mm}^{3} \mathrm{p}=0.004\right)$ and lower values of alanine aminotransferase (ALT) $(48 \mathrm{IU} / \mathrm{L}$ versus $75.6 \mathrm{IU} / \mathrm{L} \mathrm{p}=0.016)$ than HIV-negative patients. HIV-positive status (hazard ratio $=0.423, \mathrm{p}=0.023)$ and anemia $(\mathrm{HR}=0.205, \mathrm{p}=0.002)$ were independent negative predictors of complete clinical response following antileishmanial treatment initiation. Conclusions: This study reinforces that all patients with VL should be tested for HIV infection, regardless of their clinical picture. This practice would allow early recognition of coinfection with initiation of antiretroviral therapy and, possibly, reduction in treatment failure.
\end{abstract}

Keywords: Visceral leishmaniasis. HIV. Coinfection. Treatment.

\section{RESUMO}

Introdução: No Brasil, há uma grande área de sobreposição de leishmaniose visceral (LV) e infecção pelo HIV, o que favoreceu o aumento da incidência de co-infecção Leishmania/HIV. Métodos: Este estudo avaliou a resposta clínica ao tratamento de 65 pacientes em dois centros de referência de saúde em Belo Horizonte, Brasil. Resultados: O quadro clínico inicial foi semelhante entre os dois grupos, exceto pela maior frequência de diarréia e linfadenomegalia periférica em indivíduos infectados pelo HIV. Pacientes HIV-positivos apresentaram menor contagem de linfócitos no sangue $\left(686 / \mathrm{mm}^{3}\right.$ versus $\left.948 / \mathrm{mm}^{3} \mathrm{p}=0,004\right)$ e menores valores de alanina aminotransferase (ALT) (48UI/L versus75,6UI/Lp $=0,016)$ do que pacientes HIV-negativos. Infecção pelo HIV-1 (hazard ratio- $\mathrm{HR}=0,423, \mathrm{p}=0,023$ ) e anemia $(\mathrm{HR}=0,205, \mathrm{p}=0,002)$ foram preditores independentes de resposta clínica incompleta após o início do tratamento leishmanicida. Conclusões: Este estudo reforça a indicação de testagem para HIV em todos os pacientes diagnosticados com LV. O procedimento permitiria o reconhecimento precoce da co-infecção, levando à adequação do manejo clínico e o início da terapia antirretroviral, aumentando as chances de sucesso terapêutico.

Palavras-chaves: Leishmaniose visceral. HIV. Co-infecção. Tratamento.

1. Faculdade de Medicina, Universidade Federal de Minas Gerais, Belo Horizonte, MG. 2. Laboratório de Pesquisas Clínicas, Centro de Pesquisas René Rachou, Fundação Oswaldo Cruz, Belo Horizonte, MG. Address to: Dra. Ana Rabello. Av. Augusto de Lima 1715, Barro Preto, 30190-002 Belo Horizonte, MG, Brasil.

Phone: $55313349-7700$

e-mail: ana@cpqrr.fiocruz.br

Received in $14 / 10 / 2011$

Accepted in 10/01/2012

\section{INTRODUCTION}

The outbreak of human immunodeficiency virus/acquired immunodeficiency syndrome (HIV/ AIDS) during the past 30 years changed the clinical and epidemiological pattern of visceral leishmaniasis (VL) in many parts of the world. Since the mid-1980's, when the first case of Leishmania/HIV coinfection was reported, the incidence of coinfection has steadily increased and, at the end of the 90s, it had been reported in 35 countries $^{1,2}$.

The majority of the cases in South America are reported in Brazil, where there is a large endemic area for VL with a strong trend to urbanization. At the same time, HIV infection has spread into back country and rural areas, where most cases of $\mathrm{VL}$ are reported ${ }^{3}$. In general, patients with coinfection show clinical features very similar to classical VL, although atypical clinical presentations are more frequent in HIV-positive patients. Typically, coinfected patients present with intense parasitism and have low antibody response. This favors parasitological diagnosis through bone marrow or spleen aspirates and turn serological tests less sensitive than in HIV-negative patients ${ }^{4,5}$. CD4+ (cluster of differentiation)T lymphocytes counts are lower than 200 cells $/ \mathrm{mm}^{3}$ in $62-92 \%$ of coinfected patients and lower than 50 cells $/ \mathrm{mm}^{3}$ in $42 \%{ }^{6-8}$.

Classically, Leishmania/HIV coinfection is treated with the same drugs prescribed for classical VL (i.e., pentavalent antimonials and amphotericin B, desoxicolate or lipidic formulations), but the optimal dosage and the duration of treatment remains to be determined. Only $17-56 \%$ of patients show complete clinical response after the first course of therapy ${ }^{9,10}$. Pentavalent antimonials exhibit more toxicity in HIV-infected patients, and $11-28 \%$ of patients may need to interrupt therapy due to adverse events ${ }^{10,11}$.

In this study, the clinical and laboratorial features of HIV-negative and HIV-positive patients with visceral leishmaniasis in Brazil were compared. Factors associated with early clinical response after antileishmanial therapy initiation were analyzed. 


\section{METHODS}

A retrospective cohort study was conducted using medical records of consecutive patients diagnosed with the first episode of confirmed VL between January 2000 and December 2005 at two referral centers for leishmaniasis in Belo Horizonte, Brazil: Centro de Pesquisas René Rachou and Hospital Eduardo de Menezes. The following data were gathered from clinical records using standardized forms: age, gender, HIV status, CD4+ Tcell count, clinical signs/ symptoms, blood cells counts and renal and liver function tests.

Patients with clinical suspicion of VL and laboratory confirmation were included. Laboratory-confirmed VL was deemed in the presence of a positive indirect fluorescent antibody test (i.e, $\geq 1: 80$ ) or in the presence of clinical specimens (spleen or bone marrow aspirate, liver biopsy) with amastigotes, positive culture or parasite genome sequences detected by polymerase chain reaction. Patients with a past history of VL were excluded.

Categorical variables were summarized as percentage and continuous variables as mean ( $\pm \mathrm{SD}$; standard deviation) or median

\section{RESULTS}

Sixty-five patients (27 HIV-positive and $38 \mathrm{HIV}$-negative) entered the study. Mean age was 37.6 years-old $( \pm 12.1)$ and $81.5 \%$ were male. Human immunodeficiency virus patients had a median plasma CD4+ Tcell count of 123 cells $/ \mathrm{mm}^{3}(\mathrm{IQR}=66-280)$. At baseline (Table 1), the clinical picture was similar between both groups, except by diarrhea and peripheral lymphadenomegaly, more frequent in HIV-infected subjects. Human immunodeficiency virus-positive patients had lower median blood lymphocyte counts [686/ $\mathrm{mm}^{3}$ (468-686) vs. $948 / \mathrm{mm}^{3}$ (673.5-1227); $\left.\mathrm{p}=0.004\right]$ and serum alanine aminotransferase [48IU/L (29-63) versus 75.6IU/L (36-107); $\mathrm{p}=0.016]$ than HIV-negative patients.

Human immunodeficiency virus infection was diagnosed at the moment of the first VL episode in $55.6 \%$ of the patients. Sixty-one patients initiated treatment with meglumine antimoniate; nine individuals discontinued the drug prematurely due to adverse events [pancreatitis (6), severe arthralgia (2), cardiotoxicity (1)] and received full courses of amphotericin B. Four patients initiated
(IQR; interquartile range). Continuous variables were categorized based on clinically relevant criteria. Univariate comparisons of clinical and laboratory characteristics between HIV-positive and HIV-negative patients at baseline (i.e, before initiation of antileishmanial treatment) were conducted by means of Student's $t$ test or MannWhitney's $U$ test for continuous variables, and by means of Pearson's qui-square test or Fisher's exact test for categorical variables, as appropriate.

The primary endpoint for this study was the time until the occurrence of complete clinical response after antileishmanial treatment initiation. Complete clinical response was defined as the resolution of all clinical signs and symptoms present before treatment initiation. Patients who died before treatment completion were considered nonresponders. The unadjusted association between baseline patients' characteristics and the outcome variable was initially assessed by means of Cox proportional hazards regression analysis. Afterward, a multivariate Cox proportional hazards model was fit using all variables significant at $p \leq 0.25$ in univariate analysis. The likelihood ratio test with forward and backward stepwise elimination was used for variable selection. Results are reported as hazard ratios (HR) and 95\% confidence intervals (CI). The proportional hazards assumption was verified using baseline hazard function plots and the log-minus-log test of proportionality. The value of $\mathrm{p}<0.05$ was considered statistically significant. Statistical Package for the Social Sciences (SPSS) for Windows (version 10.0, SPSS Inc., Chicago, IL) was used for statistical analysis.

\section{Ethical considerations}

The study was approved by the Universidade Federal de Minas Gerais and Centro de Pesquisas René Rachou of the Fundação Oswaldo Cruz Institutional Review Boards.
TABLE 1 - Clinical and laboratorial features of HIV-negative and HIV-positive patients with visceral leishmaniasis.

\begin{tabular}{|c|c|c|c|}
\hline Variable & $\begin{array}{c}\text { HIV-negative } \\
\quad(\mathbf{n}=\mathbf{3 8})\end{array}$ & $\begin{array}{c}\text { HIV-positive } \\
\quad(\mathbf{n}=\mathbf{2 7})\end{array}$ & $\begin{array}{c}P \\
\text { value }\end{array}$ \\
\hline Age(years); mean (SD) & $37.6(13.0)$ & $37.6(10.9)$ & $0.98^{\mathrm{a}}$ \\
\hline Sex (male) & $31(81.6)$ & $22(81.5)$ & $1^{\mathrm{b}}$ \\
\hline Fever & $37(97.4)$ & $24(88.9)$ & $0.299^{\mathrm{b}}$ \\
\hline Cough & $20(52.6)$ & $18(66.7)$ & $0.258^{\mathrm{C}}$ \\
\hline Diarrhea & $7(18.4)$ & $11(40.7)$ & $0.048^{\mathrm{c}}$ \\
\hline Abdominal pain & $14(36.8)$ & $6(22.2)$ & $0.208^{\mathrm{c}}$ \\
\hline Spontaneous bleeding & $6(15.8)$ & $7(25.9)$ & $0.314^{\mathrm{c}}$ \\
\hline Peripheral edema & $4(10.5)$ & $1(3.7)$ & $0.393^{\mathrm{b}}$ \\
\hline Jaundice & $11(28.9)$ & $6(22.2)$ & $0.543^{\mathrm{C}}$ \\
\hline Splenomegaly & $31(81.6)$ & $21(77.8)$ & $0.706^{\mathrm{c}}$ \\
\hline Hepatomegaly & $34(89.5)$ & $21(77.8)$ & $0.297^{\mathrm{b}}$ \\
\hline Peripheral lymphadenomegaly & $5(13.2)$ & $9(33.3)$ & $0.051^{\mathrm{C}}$ \\
\hline Clinical signs/symptoms (n); mean (SD) & $4.5(1.5)$ & $4.6(1.2)$ & $0.677^{\mathrm{a}}$ \\
\hline Hemoglobin $(\mathrm{g} / \mathrm{dl}) ;$ mean $(\mathrm{SD})$ & $9.0(2.0)$ & $8.4(1.9)$ & $0.225^{\mathrm{a}}$ \\
\hline Anemia & $33(86.8)$ & $26(96.3)$ & $0.388^{\mathrm{b}}$ \\
\hline Blood leukocytes $\left(\mathrm{mm}^{3}\right)$; mean $(\mathrm{SD})$ & $3,083(2,430)$ & $2,341(1,101)$ & $0.144^{\mathrm{a}}$ \\
\hline Leukopenia & $31(81.6)$ & $23(85.2)$ & $0.751^{\mathrm{b}}$ \\
\hline Blood lymphocytes $\left(\mathrm{mm}^{3}\right)$; mean (SD) & $948(500)$ & $686(293)$ & $0.004^{\mathrm{a}}$ \\
\hline Lymphopenia & $20(52.6)$ & $22(81.5)$ & $0.017^{\mathrm{c}}$ \\
\hline Blood eosinophils $\left(\mathrm{mm}^{3}\right)$; median (IQR) & $21,3(12.8-43.8)$ & $28(11-52)$ & $0.608^{\mathrm{d}}$ \\
\hline Eosinopenia & $29(76.3)$ & $19(70.4)$ & $0.591^{\mathrm{C}}$ \\
\hline Blood platelets $\left(\mathrm{mm}^{3}\right)$; mean $(\mathrm{SD})$ & $139,882(112,335)$ & $142,148(65,706)$ & $0.925^{\mathrm{a}}$ \\
\hline Thrombocytopenia & $29(76.3)$ & $17(63.0)$ & $0.243^{\mathrm{c}}$ \\
\hline Serum creatinine (mg/dl); mean $(\mathrm{SD})$ & $1.2(0.6)$ & $1.0(0.5)$ & $0,343^{\mathrm{a}}$ \\
\hline $\operatorname{AST}(\mathrm{IU} / \mathrm{L}) ;$ mean $(\mathrm{SD})$ & $84.2(100.7)$ & $77.5(60.4)$ & $0.759^{\mathrm{a}}$ \\
\hline AST $>1.5$ versus ULN & $18(47.4)$ & $13(48.1)$ & $0.951^{\mathrm{C}}$ \\
\hline $\operatorname{ALT}(\mathrm{IU} / \mathrm{L}) ;$ mean (SD)] & $75.6(61.3)$ & $47.9(25.8)$ & $0.016^{\mathrm{a}}$ \\
\hline ALT $>1.5$ versus ULN & $16(42.1)$ & $8(29.6)$ & $0.304^{\mathrm{C}}$ \\
\hline
\end{tabular}

Values are $\mathrm{n}(\%)$, unless indicated otherwise. HIV: human immunodeficiency virus; $\mathbf{n}$ : number; $\mathbf{g} / \mathbf{d l}$ : grams per deciliter; $\mathbf{m m}^{\mathbf{3}}$ : per cubic millimeter; $\mathbf{m g} / \mathbf{d l}$ : milligrams per deciliter; SD: standard deviation; IQR: interquartile range; AST: aspartate aminotransferase; ALT: alanine aminotransferase; ULN: upper limit of normal. ${ }^{a}$ by Student's $t$ test; ${ }^{b}$ by Fisher's exact test; ${ }^{c}$ by Pearson's qui-square test; d by Mann-Whitney's $U$ test. 
treatment with amphotericin B, but this drug was switched to meglumine antimoniate in one patient due to acute renal failure after total recovery of renal function. Median follow-up was 20 days $(\mathrm{IQR}=13-28)$ for HIV-positive patients and 21 days (IQR $=13.5-30)$ for HIV-negative patients. Eight patients (six HIV-positive and two HIV-negative) died at a median follow-up of 13.5 days.

Univariate associations between patients' baseline factors and time to complete clinical cure following antileishmanial treatment initiation are described in Table 2. After adjusting for confounders, HIV-positive status $(\mathrm{HR}=0.423,95 \% \mathrm{CI}=0.202$ $0.888 ; \mathrm{p}=0.023)$ and anemia $(\mathrm{HR}=0.205,95 \% \mathrm{CI}=0.074-0.568$; $\mathrm{p}=0.002$ ) remained as independent (negative) predictors of complete clinical cure.

\section{DISCUSSION}

The clinical presentation of VL in HIV-infected patients did not differ from that classically described for VL in HIV-negative subjects, as most patients in both groups showed the classical triad of fever, splenomegaly and citopenia. In fact, clinical manifestations of VL caused by L. infantum and L. donovani in HIV-infected patients are not significantly different from those in non-HIVinfected patients ${ }^{1,6,7,8}$. Classical features commonly present are fever, weight loss, hepatosplenomegaly, and pancytopenia. Some authors, however, reported atypical clinical manifestations in coinfected patients, lacking visceromegalies or fever ${ }^{9,12,13}$. Visceral leishmaniasis is a broad clinical spectrum disease, so atypical forms of presentation are relatively frequent.

In this study, higher frequency of diarrhea in HIV positive patients, which is not a clinical manifestation commonly reported in patients with VL. Diarrhea that could not be explained by any other condition was found in $7.7 \%$ of coinfected patients ${ }^{14}$. In coinfected patients, intestinal infections and concomitant use of antimicrobials and/or antiretrovirals may explain the higher frequency of diarrhea.

In this group, low total lymphocyte count was associated with HIV infection. CD4+ T cell count was lower than 200 cells $/ \mathrm{mm}^{3}$ in $75 \%$ of coinfected patients. The low lymphocytes counts observed in HIV-positive patients, due to depletion of CD4+ T cells seen in HIV infection, was largely reported in coinfected patients in the Mediterranean basin ${ }^{9,10,11,15}$. At the time of clinical presentation of VL, 79 to $100 \%$ of HIV-positive patients coinfected with L. infantum have CD4+ cell counts lower than 200 cells $/ \mathrm{mm}^{3}$. Low CD4+ T cell counts may prevent a full clinical recovery and is associated with multiple relapses ${ }^{8,11}$.

Human immunodeficiency virus infection was an independent predictor of poorer clinical response to treatment in this studygroup. Using the treatment regimens recommended by the Brazilian Ministry of Health ${ }^{16}$ most HIV-negative patients with VL show clinical improvement, very often before the end of therapy. In coinfected patients, however, a number of studies reported higher treatment failure and higher lethality rates, regardless of the treatment schedule used ${ }^{10,11,13-15}$. Lower response rate in HIV-infected compared to HIV-negative individuals (54.8\% versus $89.7 \%$ ) was reported ${ }^{11}$. More recently, a high proportion of treatment failure was observed in
TABLE 2 -Unadjusted relationships between baseline variables and complete clinical response, Cox proportional hazards models.

\begin{tabular}{|c|c|c|c|}
\hline Variable & Hazard ratio & $95 \% \mathrm{CI}$ & Pvalue \\
\hline Age (per year increase) & 0.976 & $0.946-1.008$ & 0.136 \\
\hline Sex (male) & 1.024 & $0.465-2.257$ & 0.952 \\
\hline HIV infection & 0.423 & $0.203-0.884$ & 0.022 \\
\hline Fever & 1.389 & $0.421-4.582$ & 0.590 \\
\hline Cough & 0.897 & $0.459-1.754$ & 0.751 \\
\hline Diarrhea & 0.413 & $0.171-0.998$ & 0.049 \\
\hline Abdominal pain & 0.863 & $0.414-1.799$ & 0.694 \\
\hline Spontaneous bleeding $^{\mathrm{a}}$ & 1.030 & $0.448-2.366$ & 0.945 \\
\hline Peripheral edema & 1.474 & $0.443-4.908$ & 0.527 \\
\hline Jaundice mean (SD) & 1.143 & $0.534-2.444$ & 0.731 \\
\hline Splenomegaly & 0.802 & $0.345-1.863$ & 0.608 \\
\hline Hepatomegaly & 1.042 & $0.432-2.515$ & 0.927 \\
\hline Peripheral lymphadenomegaly & 1.017 & $0.474-2.183$ & 0.966 \\
\hline Clinical signs/symptoms (per unit increase) & 0.891 & $0.667-1.190$ & 0.434 \\
\hline Anemia ${ }^{b, c}$ & 0.205 & $0.075-0.561$ & 0.002 \\
\hline Leukopenia $\mathrm{b}, \mathrm{d}$ & 0.550 & $0.223-1.357$ & 0.195 \\
\hline Lymphopenia ${ }^{b, e}$ & 0.740 & $0.382-1.434$ & 0.372 \\
\hline Eosinopenia $^{b, f}$ & 1.316 & $0.615-2.814$ & 0.479 \\
\hline Thrombocytopenia ${ }^{b, g}$ & 1.002 & $0.491-2.046$ & 0.996 \\
\hline Serum creatinine (per $1 \mathrm{mg} / \mathrm{dl}$ increase) & 1.328 & $0.605-2.916$ & 0.480 \\
\hline $\mathrm{AST}>1.5 \times \mathrm{ULN}^{\mathrm{b}}$ & 1.249 & $0.649-2.404$ & 0.506 \\
\hline $\mathrm{ALT}>1.5 \times \mathrm{ULN}^{\mathrm{b}}$ & 1.308 & $0.675-2.535$ & 0.426 \\
\hline Treatment with amphotericin B & 0.544 & $0.190-1.553$ & 0.255 \\
\hline
\end{tabular}

95\%CI: 95\% confidence interval; HIV: human immunodeficiency virus; SD: standard deviation; mg/dl: milligrams per deciliter; AST: aspartate aminotransferase; ALT: alanine

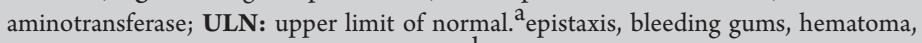
hemoptysis, hematemesis, enterorrhagia; ${ }^{b}$ sensitivity analyses were performed to assess the effect of choosing alternative cutoff points and of treating these variables as continuous instead of categorical; ${ }^{c}$ hemoglobin $<11 \mathrm{~g} / \mathrm{dl}$; $\mathrm{d}_{\text {leukocytes }}<4,000 / \mathrm{mm}^{3}$; elymphocytes $<1,000 / \mathrm{mm}^{3 ;}$ e $\mathrm{f}_{\text {eosinophils }<50 / \mathrm{mm}^{3} \text {; }}$ platelets $<150,000 / \mathrm{mm}^{3}$.

coinfected patients treated with miltefosine (failure occurred in 18\% of HIV-coinfected patients, compared with $5 \%$ of non-HIV-infected patients $)^{17}$. High frequency of adverse events due to antileishmanial treatment has also been reported. Adverse effects were observed in $56 \%$ of coinfected patients when antimonials were used without the upper limit of dosage, and in $28 \%$ of patients, treatment with meglumine antimoniate was permanently discontinued due to serious adverse effects ${ }^{10,11}$. In a study from Ethiopia, $1 / 3$ of coinfected patients died due to treatment-related pancreatitis ${ }^{17}$. In our study, $9(14.8 \%)$ out of 61 individuals who started treatment with antimonials discontinued the drug due to adverse events. In this study, anemia was also a predictor of worse clinical outcome after treatment. It is possible that lower hemoglobin levels may serve as a proxy for the severity of the patients' illness or advanced immunossupression. In HIV patients coinfected with Leishmania spp. thrombocytopenia was identified as independent predict or of mortality, with each reduction of 10,000 platelets $/ \mathrm{mm}^{3}$ increasing the mortality risk ratio by $6 \%{ }^{14}$. The platelet count was not associated with increased mortality in the present study (data not shown).

This study has a number of limitations. Registration bias precluded the analysis of a number of variables originally included in our study protocol (e.g., quantification of weight loss). The extent to which early clinical response predicts long-term response or even parasitological cure cannot be ascertained by our data. The small 
sample size limits the external validity of our study, thus further studies involving larger numbers of patients are needed.

The Brazilian Ministry of Health recommends that VL should be investigated in all patients infected with HIV with liver or spleen enlargement in presence or not of fever and blood cell counts. Additionally, recommends that all patients with leishmaniasis should be offered to be tested for HIV infection ${ }^{18}$. The poor and slow clinical recovering of VL among patients with HIV infection observed in this study reinforces this recommendation.

\section{ACKNOWLEDGMENTS}

The authors thank Mrs. Cerisa Baptista for the technical assistance.

\section{CONFLICT OF INTEREST}

The authors declare that there is no conflict of interest.

\section{FINANCIAL SUPPORT}

This study was financed by the Brazilian National Council of Technological and Scientific Development (CNPq), Centro de Pesquisas René Rachou (CpqRR)/Fundação Oswaldo Cruz (FIOCRUZ) and Universidade Federal de Minas Gerais (UFMG).

\section{REFERENCES}

1. De laLoma A, Alvar J, Martínez-Galiano E, Blázquez J, Alcalá-Muñoz A, Nájera R. Leishmaniasisor AIDS.Trans R Soc Trop Med Hyg 1985; 79:421-422.

2. World Health Organization (WHO). Leishmaniasis and HIV coinfection [Internet].WHO; [cited 2011 September 10] Available from: http://www.who.int/ leishmaniasis/burden/hiv_coinfection/burden_hiv_coinfection/en/index.html/.

3. Rabello A, Orsini M, Disch J. Leishmania/HIV co-infection in Brazil: an appraisal. Ann Trop Med Parasitol 2003; 97:S17-S28.

4. Malik AN, John L, Bruceson AD, Lockwood DN.Changing pattern of Visceral Leishmaniasis, United Kingdom, 1985-2004. Emerg Infect Dis 2006;12: 1257-1259.

5. Medrano FJ, Canavate C, Leal M, Rey C, Lissen E, Alvar J. The role of serology in the diagnosis and prognosis of visceral leishmaniasis in patients coinfected with human immunodeficiency virus type-1. Am J Trop Med Hyg 1998; 59:155-162.

6. Desjeux P, Alvar J. Leishmania/HIV co-infections: epidemiology in Europe. Ann Trop Med Parasitol 2003; 97:3-15.

7. Cruz I, Nieto J, Moreno J, Canavate C, Desjeux P, Alvar J. Leishmania/HIV coinfections in the second decade. Indian J Med Res 2006; 123:357-388.

8. Alvar J, Aparicio P, Aseffa A, Den Boer M, Cañavate C, Dedet JP, et al. The Relationship between Leishmaniasis and AIDS: the Second 10 Years. Clin Microbiol Rev 2008;21:334-359.

9. Sundar S, Rai M. Laboratory Diagnosis of Visceral Leishmaniasis. Clin Diagn Lab Immunol 2002; 9:951-958.

10. Delgado J, Macías J, Piñeda JA, Corzo JA, González-Moreno MP, De La Rosa $\mathrm{R}$, et al. High frequency of serious side effects from meglumineantimoniate given without an upper limit dose for the treatment of visceral leishmaniasis in human immunodeficiency virus type-1- infected patients. Am J Trop Med Hyg, 1999; 6:766-769.

11. Pintado V, Martín-Rabadán P, Rivera ML, Moreno S,Bouza E. Visceral leishmaniasis in human immunodeficiency virus (HIV)-infected and non HIV infected patients. Medicine 2001; 80:54-73.

12. Santos M, Marques RC, Farias CA, Vasconcelos DM, Stewart JM, Costa DL, et al. Predictors of an unsatisfactory response to pentavalent antimony in thetreatment of American visceral leishmaniasis. Rev Soc Bras Med Trop 2002; 35:629-633.
13. Rosenthal E, Marty P, Cassuto JR. Visceral leishmaniasis and HIV-1 co-infection in southern France. Trans R Soc Trop Med Hyg 1995; 89:159-162.

14. López-Vélez R, Pérez-Molina JA, Guerrero A, Baquero F, Villarrubia J, Escribano L, et al. Clinicoepidemiologic characteristics, prognostic factors, and survival analysis of patients coinfected with human immunodeficiency virus and Leishmaniain an area of Madrid, Spain. Am J Trop Med Hyg1998; 58:436-443.

15. Russo R, Laguna F, López-Vélez R, Medrano FJ, Rosenthal E, Cacopardo B, et al. Visceral leishmaniasis in those infected with HIV: clinical aspects and other opportunistic infections. Ann Trop Med Parasitol 2003; 97:S99-S105.

16. Ministério da Saúde, Departamento de Vigilância Epidemiológica, Secretaria de Vigilância em Saúde. Manual de vigilância e controle da leishmaniose visceral. Brasília: Ministério da Saúde; 2004.

17. Ritmeijer K, Dejenie A, Assefa Y, Hundie TB, Mesure J, Boots G, et al. A comparison of miltefosine and sodium stibogluconate for treatment of visceral leishmaniasis in an Ethiopian population with high prevalence of HIV infection. Clin Infect Dis 2006; 43:357-364.

18. Ministério da Saúde, Secretaria de Vigilância em Saúde. Manifestações Clínicas In: Saúde MD, editor. Manual de recomendações para diagnóstico, tratamento e acompanhamento de pacientes com a coinfecçãoLeishmania-HIV. Brasilia: Ministério da Saúde; 2011. p. 14-19. 